\title{
ORGANOCLAY ADDITIVE FOR PLYWOOD PROTECTION AGAINST BROWN AND WHITE ROT FUNGI
}

\author{
Zanete Zommere $^{1}$, Ilze Irbe ${ }^{1}$, Juris Grinins ${ }^{1}$, Sanita Rudzite ${ }^{2}$, Vizma Nikolajeva ${ }^{3}$ \\ ${ }^{1}$ Latvian State Institute of Wood Chemistry, Latvia \\ ${ }^{2}$ AS "Latvijas Finieris", Latvia \\ ${ }^{3}$ University of Latvia, Latvia \\ zommerzanete@gmail.com
}

\begin{abstract}
In this study, antifungal properties of an organoclay additive were investigated. Two types of organoclay (red and white) were tested in Petri dishes to determine their toxicity against the brown rot fungus Coniophora puteana and the white rot fungus Trametes versicolor. Red organoclay was more efficient than the white one and, depending on the fungus, inhibited or stopped the fungal growth. Red organoclay was chosen as an additive to produce a new type of plywood product. Biological durability of this plywood product was determined according to the methods: NF B 51-295 (bending strength test) and LVS ENV 12038:2002 (mass loss test). The loss in bending strength exceeded $81 \%$ and $65 \%$ after exposure to brown and white rot fungi, respectively. The mass loss of the plywood product after the decay test was higher than $3 \%$, which defined the material as not fully resistant against decay fungi. According to CEN/TS 15083-1:2005, the plywood product corresponded to the durability class 3 (moderately durable) to 5 (not durable) depending on the fungus.
\end{abstract}

Key words: plywood, rot fungi, protection, organoclay.

\section{Introduction}

The properties of microbial growth inhibition are among the main tasks while developing new materials for the building industry. One of the most promising materials with antimicrobial properties is clay. It is common all over the world, it is relatively easy to obtain and has a large relative surface area. It is also possible to modify clay to improve its natural properties. All types of antimicrobial clay are mineralogically different but they all have high iron content. They contain smectites, biotite, jarosite, magnetite and other minerals. It is suggested that the presence of pyrite could be one of the most significant factors for providing antimicrobial properties for clay, although not all antimicrobial clays contain pyrites (Parolo et al., 2011; Williams et al., 2011).

Biodegradation has a big influence on the life cycles of various materials. It is very important to create not only recyclable materials but also long-lasting materials that are resistant against microorganisms. Among the biggest groups of organisms that degrade various materials are fungi (Schmidt, 2006; Leja \& Lewandowicz, 2010). Especially vulnerable to fungal degradation is wood and wood-based products (Goodell, Nicholas \& Schultz, 2003). Plywood is widely used in furniture production and building construction for both interior and exterior applications due to better dimensional stability compared to solid wood. The properties of plywood are mostly determined by the quality of veneer layers, their placement, the adhesive used and the bonding conditions (Youngquist, 1999). However, the application of plywood in exterior conditions is limited due to the sensitivity to moisture and biodegradation (Baileys et al., 2003). It has been reported that during 24 months of outdoor exposure several types of impregnated, laminated or natural plywood made out of birch, okoume and radiata pine veneers have been resistant against wood decay fungi (Irbe et al., 2016).

Modification of clay can improve its durability properties. Cation exchange reactions that allow various changes of surface activity properties are the most popular types of modification (Lira et al., 2017; Parolo et al., 2011). Recently, the antifungal effects of modified clay against the microscopic fungi Alternaria alternata and Cladosporium herbatum have been studied (Lazdina, Obuka, \& Nikolajeva, 2017). In three of the four tested samples, the antimicrobial activity was observed. The effects of nano-clay on the biological durability of wood-plastic composites (WPCs), made from polypropylene and poplar sawdust, against five important wood-deteriorating fungi were studied by Bari et al. (2015). It was found that nano-clay significantly decreased the mass loss of WPCs by all five fungi tested.

The aim of this study was to determine whether an organoclay additive has antifungal properties and if it can be used for protection of birch plywood against brown and white rot fungi.

\section{Materials and Methods}

Two types of organoclay additives (red and white) were selected for the Petri dish test to determine their anti-fungal properties. Red and white organoclay had different mineral compositions and contained an active ingredient trimethyloctadecylammonium chloride (CAS 112-03-8). Both types of organoclay were added to malt agar culture medium (3\% agar, 5\% malt extract) after sterilization in concentrations of $0.2 \%$, 2\%, 3\%, 4\%. Later the Petri dishes with organoclay 
additives were inoculated with the brown rot fungus Coniophora puteana (Schumacher ex Fries) Karsten (BAM Ebw. 15) and the white rot fungus Trametes versicolor (Linnaeus) Quélet (FPRL 40C). Inoculum in diameter of $10 \mathrm{~mm}$ was placed in the centre of each Petri dish. Radial growth of fungal colonies was measured within a 25-day period. The percentage of coverage was compared with control Petri dishes with no organoclay added. Three replicates were used for each concentration and control.

The quantitative determination of iron in both types of organoclay was performed by an atomic absorption spectrometer (AAS) contrAA 700 (Analytik Jena AG) according to the standard LVS ISO 11466:1995. The dried sample was extracted with a mixture of hydrochloric acid/ nitric acid for $16 \mathrm{~h}$ at room temperature, followed by boiling for $2 \mathrm{~h}$. Then, the extractive was diluted with a nitric acid solution.

Birch plywood with/ without the organoclay additive was used for biological durability tests according to the standards NF B 51-295:1980 (bending strength test) and LVS ENV 12038:2002 (mass loss test). Only red organoclay was chosen as the additive. There were two types of plywood: A plywood without organoclay, glued with phenol-formaldehyde (PF) resin and laminated with impregnated film; B plywood glued with PF resin, containing the organoclay additive (5\% of the dry mass of resin) and laminated with impregnated film, containing the organoclay additive (12\% of the dry mass of the film).

For the standard NF B 51-295:1980, plywood samples with the sizes of $190 \times 15 \times 15 \mathrm{~mm}$ were conditioned at the temperature of $20{ }^{\circ} \mathrm{C}$ and $65 \%$ relative humidity $(\mathrm{RH})$ and then subjected to ageing procedures. The evaporation test was done in a wind tunnel at the temperature of $40{ }^{\circ} \mathrm{C}$ and the air flow of $1 \mathrm{~m} \mathrm{~s}^{-1}$ for four weeks. Afterwards the leaching test was performed by submerging the samples in distilled water at $20{ }^{\circ} \mathrm{C}$ for one week. After soaking, the samples were returned to the conditioning chamber for two weeks until reaching the constant mass. Then, the samples were sterilized with gamma irradiation of 1.5 Mrad. Two samples were placed in each Roux dish with the fungi $C$. puteana and $T$. versicolor on a malt agar medium. Control samples were placed in Roux dishes with the medium but without fungal cultures. The test lasted for 12 weeks in a cultivation camber at $22{ }^{\circ} \mathrm{C}$ and $70 \% \mathrm{RH}$. After the test, the samples were withdrawn from the dishes, brushed free of mycelium and placed in a conditioning chamber for four weeks before the bending test. The breaking stress during bending was determined using a material testing device Zwick Roell Z010. The distance between the bending supports was $150 \mathrm{~mm}$. Mean breaking stress was calculated for each series.
For the standard LVS ENV 12038:2002, plywood samples with the sizes of $50 \times 25 \times 15 \mathrm{~mm}$ were subjected to conditioning and ageing procedures as described earlier. Prior to sterilization, the initial conditioned mass $\left(m_{0}\right)$ was determined. Sterilized samples were placed in Kolle flasks with $C$. puteana and $T$. versicolor cultures. In each Kolle flask, two samples were placed on glass supports to isolate them from a direct contact with the mycelium. The test lasted for 12 weeks in a cultivation chamber at $22{ }^{\circ} \mathrm{C}$ and $70 \% \mathrm{RH}$. After the test, the samples were withdrawn from the flasks and brushed free of mycelium. The wet mass $\left(m_{2}\right)$ was determined by weighting each specimen to the nearest $0.01 \mathrm{~g}$. Samples were held in a conditioning chamber to regain the constant mass and then dried in oven at $103{ }^{\circ} \mathrm{C}$ for $8 \mathrm{~h}$, and the final dry mass $\left(m_{3}\right)$ was measured. Moisture content (MC) check specimens were used to determine the oven dry mass for the test specimens attacked by the fungi. These MC check specimens were pre-conditioned to the constant mass and weighted to determine the initial conditioned mass $\left(m_{0}\right)$. They were placed in the oven for $8 \mathrm{~h}$, cooled to room temperature in desiccators and weighted to the nearest $0.01 \mathrm{~g}$ for the determination of the oven dry mass $\left(m_{l}\right)$. The initial moisture factor $\left(F_{i}\right)$ was calculated for each MC check specimen by the following formula (1):

$$
F_{i}=1-\frac{m_{0}-m_{1}}{m_{0}}
$$

The mean value $\left(F_{i m}\right)$ was calculated for each set of MC check specimens and used to calculate the oven dry mass $\left(m_{l}\right)$ of the equivalent set of the test specimens, using the following formula (2):

$$
F_{\mathfrak{J}} \times m_{0}=m_{1}
$$

The final MC was calculated after the determination of all masses mentioned above for each test specimen by expressing its water content $\left(m_{2} m_{3}\right)$ as the percentage of the final dry mass $\left(m_{3}\right)$. The mass loss (ML) of each test specimen was calculated by expressing the ML $\left(m_{1} m_{3}\right)$ as the percentage of the final dry mass $\left(m_{3}\right)$. The mean ML was calculated for each set of the test specimens exposed to each test fungus.

The decay susceptibility index (DSI) was calculated as (3):

$$
D S I=\frac{T}{S} \times 100
$$

where $T$ is the ML (\%) of an individual test specimen and $S$ is the mean ML (\%) of the appropriate set of control specimens.

DSI values of 100 indicate the same decay resistance as that of the timber used for the control. 


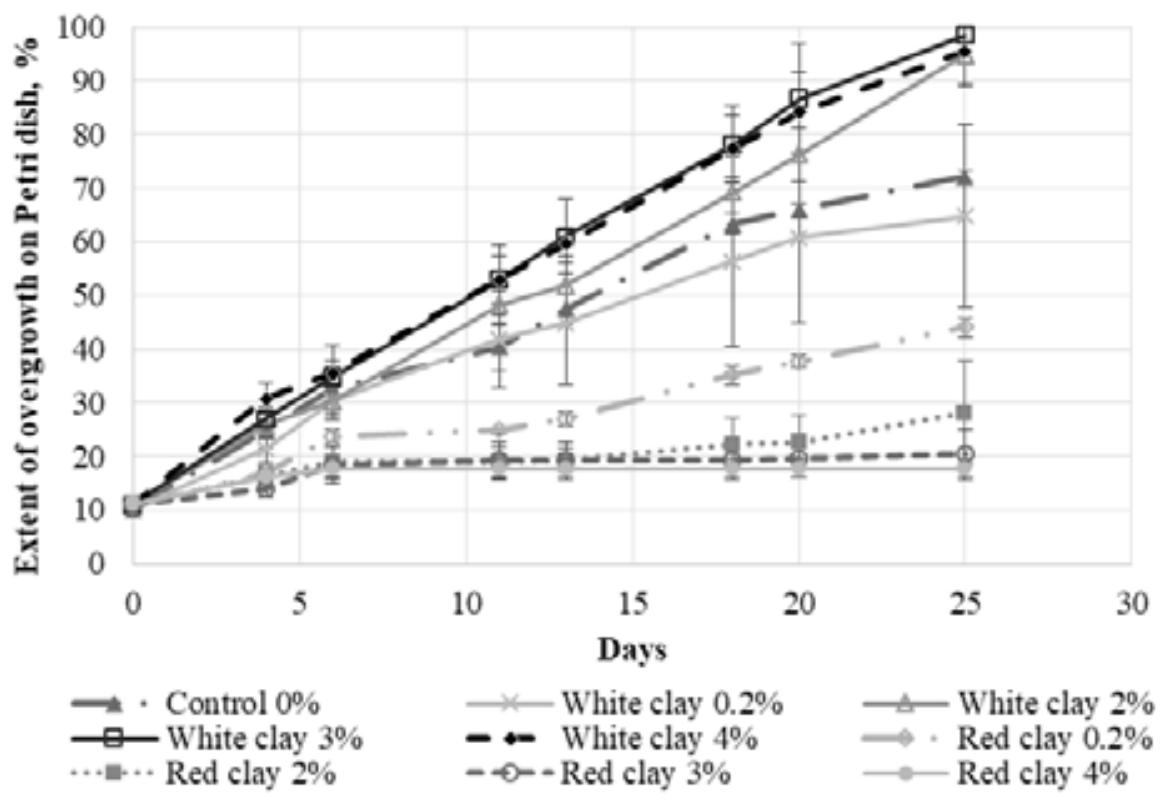

Figure 1. Effect of organoclay additives on the colony growth of the brown rot fungus C. puteana.

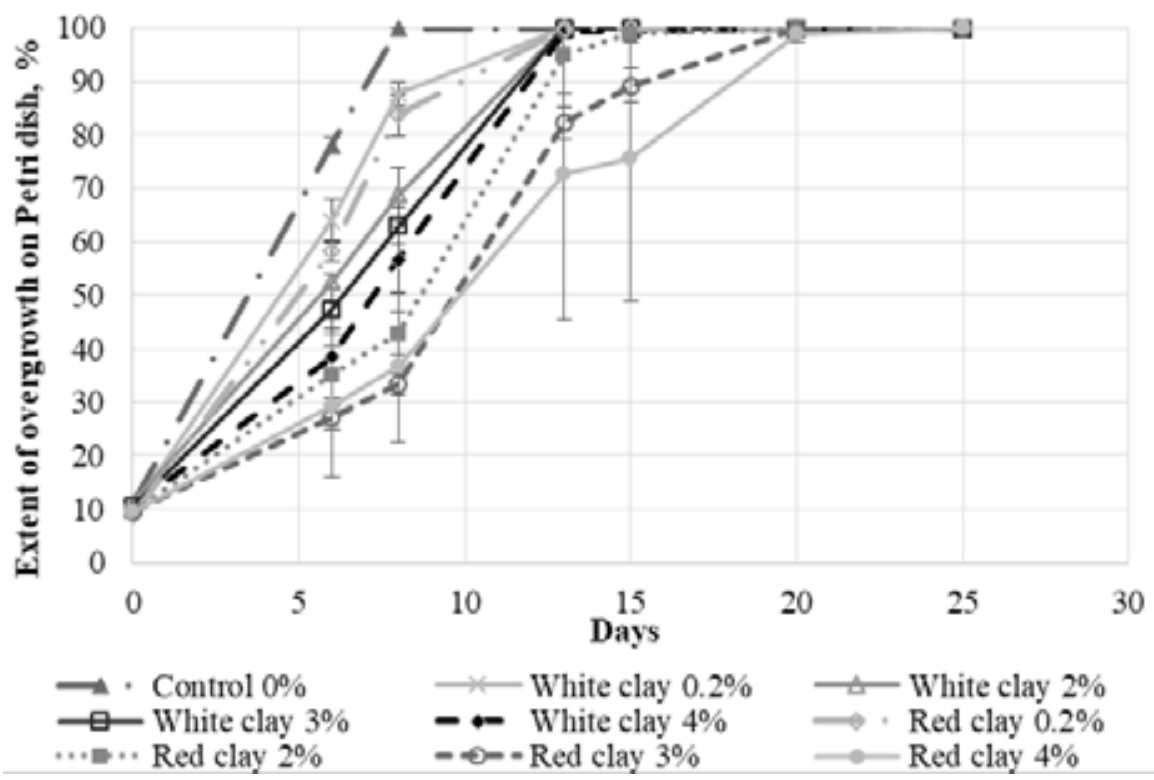

Figure 2. Effect of organoclay additives on the colony growth of the white rot fungus T. versicolor.

Materials with lower DSI values are more resistant to the fungal attack.

Virulence control test specimens were used for both plywood tests pine wood for $C$. puteana and birch wood for $T$. versicolor. Test results are valid if the ML of virulence control specimens is greater than $20 \%$.

Student's t-test was used for statistical analysis with program $\mathrm{R}$ (version 3.4.3.) to determine statistically significant differences between the sets of the test specimens. The significance level $\alpha=0.05$ was used for all tests (R Core Team, 2017; Wickham \& Bryan, 2017).

\section{Results and Discussion}

The Petri dish test with the mycelial growth of the brown rot fungus $C$. puteana on the medium containing white organoclay (Fig. 1) showed that the concentrations of $2 \%, 3 \%$ and $4 \%$ stimulated the fungal growth compared to the control. On the contrary, red organoclay in all concentrations inhibited the growth. The highest inhibiting effect was reached at concentrations of $3 \%$ and $4 \%$, when the colony growth was stopped soon after the inoculation.

Results for the mycelial growth of the white rot fungus T. versicolor (Fig. 2) indicated that both types 
of organoclay slowed down the growth compared to the control. Red organoclay showed stronger inhibition of the growth rate than white clay. However, after 20 days, all Petri dishes with both organoclay additives were covered with fungal mycelium.

The concentration of iron in both types of organoclay was determined to observe the possible toxic effect of the metal on fungal growth. It is known (Tautkus et al., 2004) that, at low concentrations, iron plays an important role in metabolic and fermentation processes as an enzyme activator, a stabilizer and a functional component of proteins. Above trace levels, however, iron has other roles. It has been stated that for all trace elements, including iron, there exists a fairly narrow concentration level between the essential and toxic levels.

Our results showed that white and red organoclay contained $33.4 \mathrm{mg} \mathrm{g}^{-1}$ (3.34\%) and $39.5 \mathrm{mg} \mathrm{g}^{-1}$ (3.95\%) of iron, respectively. This suggests that the higher concentration of iron in red organoclay could cause more pronounced inhibition of fungal growth than white clay. However, in the case of the white rot fungus $T$. versicolor, both types of organoclay could not be considered as fully toxic as the rate of the colony growth was restricted but not stopped.

Based on the results of the Petri dish test for further durability tests, only red organoclay was used to produce plywood $\mathrm{B}$.

After the bending strength test, the fungi were well developed on the specimens, which also were visually degraded. The test results according to the ML of virulence specimens $36.07 \%$ for $C$. puteana and $20.80 \%$ for $T$. versicolor were valid. Bending strength and mean strength ratio (bending strength expressed as the percentage of the relevant control) between both types of plywood were very similar (Table 1). Student's t-test also showed that there was no significant difference between the strength of plywood A and B ( $\alpha=0.05)$ exposed to fungi: $p=0.83$ for $C$. puteana and $\mathrm{p}=0.13$ for $T$. versicolor. However, there was a significant difference between the strength of the plywood exposed to C. puteana $(\mathrm{p}<0.001)$ and T. versicolor $(\mathrm{p}=0.004)$ for both types of plywood. These results suggest that, although plywood B contained the organoclay additive in both the PF glue and the impregnation film, it was not better protected against fungi than plywood A without the additive.

According to Table 1, the loss in bending strength after exposure to $C$. puteana was $81.4 \%$ and $81.8 \%$ for plywood A and plywood B, respectively. The loss in bending strength after exposure to $T$. versicolor was $65.0 \%$ and $71.3 \%$ for plywood A and B, respectively. According to the standard LVS EN 636:2012 for plywood A and B, the bending strength class had declined from class F50 to class F3 (9 classes lower) and F5 (8 classes lower) as a result of the degradation by brown and white rot fungi, respectively.

In the mass loss test, the virulence control specimens after exposure to $C$. puteana and T. versicolor had the ML of $39.5 \%$ and $21.3 \%$, respectively, which confirmed the validity of the test. Test fungi were well developed, although $C$. puteana covered all the surfaces of the test specimens, while $T$. versicolor covered the surfaces except the impregnation film. The MC of plywood specimens was above 25\%, which confirmed the validity of the test (Table 2). The ML for plywood B was higher than for plywood A after exposure to both fungi. This difference was

Table 1

Bending strength test results with SD for plywood without (A) and with (B) the organoclay additive

\begin{tabular}{|l|c|c|c|c|c|c|c|}
\hline \multirow{2}{*}{$\begin{array}{c}\text { Plywood } \\
\text { type }\end{array}$} & $\begin{array}{c}\text { Initial bending } \\
\text { strength }\end{array}$ & \multicolumn{2}{|c|}{$\begin{array}{c}\text { Bending strength after } \\
\text { artificial ageing }\end{array}$} & \multicolumn{2}{|c|}{ Final bending strength: ageing + fungus exposure } \\
\cline { 4 - 8 } & Strength, MPa & $\begin{array}{c}\text { Strength, } \\
\text { MPa }\end{array}$ & $\begin{array}{c}\text { Mean } \\
\text { strength } \\
\text { ratio, \% }\end{array}$ & $\begin{array}{c}\text { Strength, } \\
\text { MPa }\end{array}$ & $\begin{array}{c}\text { Mean strength } \\
\text { ratio, \% }\end{array}$ & $\begin{array}{c}\text { Strength, } \\
\text { MPa }\end{array}$ & $\begin{array}{c}\text { Mean } \\
\text { strength } \\
\text { ratio, \% }\end{array}$ \\
\hline A & $83.9 \pm 11.7$ & $37.2 \pm 4.3$ & $44.3 \pm 5.1$ & $6.9 \pm 1.5$ & $18.6 \pm 4.1$ & $13.0 \pm 2.3$ & $35.0 \pm 6.2$ \\
\hline B & $86.5 \pm 13.9$ & $36.9 \pm 5.9$ & $42.7 \pm 6.9$ & $6.7 \pm 1.6$ & $18.2 \pm 4.3$ & $10.6 \pm 1.9$ & $28.7 \pm 5.2$ \\
\hline
\end{tabular}

Table 2

Mass loss test results with SD for plywood without (A) and with (B) the organoclay additive

\begin{tabular}{|c|c|c|c|c|c|c|}
\hline \multirow{2}{*}{$\begin{array}{c}\text { Plywood } \\
\text { type }\end{array}$} & \multicolumn{3}{|c|}{ Specimens exposed to C. puteana } & \multicolumn{3}{c|}{ Specimens exposed to T. versicolor } \\
\cline { 2 - 7 } & Mass loss, \% & $\begin{array}{c}\text { Moisture } \\
\text { content, \% }\end{array}$ & DSI & $\begin{array}{c}\text { Mass loss, } \\
\%\end{array}$ & $\begin{array}{c}\text { Moisture } \\
\text { content, \% }\end{array}$ & DSI \\
\hline A & $26.0 \pm 6.2$ & $35.7 \pm 1.2$ & 65.9 & $10.2 \pm 3.9$ & $33.9 \pm 2.8$ & 47.6 \\
\hline B & $35.6 \pm 2.1$ & $46.7 \pm 2.5$ & 89.0 & $11.1 \pm 2.8$ & $34.8 \pm 1.6$ & 52.3 \\
\hline
\end{tabular}


statistically significant only for the test specimens exposed to attack of $C$. puteana: p-value was 0.02 . There was a statistically significant difference for ML between both fungi for both types of plywood. For both types of plywood, p-value was less than 0.001 when compared the ML between $C$. puteana and $T$. versicolor.

Both plywood types cannot be considered as fully resistant to attack by fungi as the ML of the specimens was greater than 3\%. Plywood A and B were more easily degradable by $C$. puteana. The higher decay ability of $C$. puteana was also observed by more severe degradation of virulence specimens (pinewood). The higher DSI values confirmed the lower decay resistance of materials.

According to the durability class (DC) arrangement according to CEN/TS 15083-1:2005, plywood B can be placed in DC 3 as moderately durable ( $\mathrm{ML}>10$ to $\leq 15 \%)$ and DC 5 as not durable (ML>30\%) depending on the fungus (Table 2).

Although plywood B contained the organoclay additive, it was even more degraded than plywood A. It is suggested that the addition of the organoclay to the PF glue and the impregnation film of birch plywood did not provide effective protection against white and brown rot fungi.

\section{Conclusions}

1. In the Petri dish test, red organoclay, depending on the concentration, inhibited or stopped the growth of the brown rot fungus Coniophora puteana and inhibited the growth rate of the white rot fungus Trametes versicolor. White organoclay showed only a slight decrease of growth rate by $T$. versicolor and promoted the growth of $C$. puteana.

2. There was no significant difference between the bending strength of plywood without (A) and with (B) the organoclay additive after exposure to $C$. puteana and $T$. versicolor. The loss in bending strength exceeded $81 \%$ and $65 \%$ after exposure to brown and white rot fungi, respectively.

3. The ML of plywood A and B after the decay test was higher than $3 \%$, which defined the products as not fully resistant against brown and white rot fungi.

4. The addition of red organoclay to the PF glue and the impregnation film of birch plywood did not provide effective protection against decay fungi.

\section{Acknowledgements}

The authors gratefully acknowledge the financial support by the JSC Latvijas Finieris and European Regional Development Fund (ERDF) in the framework of the project 'Forest Sector Competence Centre', 'Wood based composites with improved properties' (No 1.2.1/16/A/009). The authors thank Dr. Nina Kurnosova (LS IWC) for determination of iron by the AAS method. The organoclay was provided by ALINA startup (Latvia).

\section{References}

1. Baileys, J.K., Marks, B.M., Ross, A.S., Crawford, D.M., Krzysik, A.M., Muehl, J.H., \& Youngquist, J.A. (2003). Providing moisture and fungal protection to wood-based composites. Forest Products Journal, 53(1): 7681.

2. Bari, E., Taghiyari, H.R., Schmidt, O., Ghorbani, A., \& Aghababaei, H. (2015). Effects of nano-clay on biological resistance of woodplastic composite against five wood-deteriorating fungi. Maderas. Ciencia y Tecnología, 17(1): 205212. DOI: 10.4067/S0718-221X2015005000020.

3. European Committee for Standardization. (2005). Durability of wood and wood-based products Determination of the natural durability of solid wood against wood-destroying fungi, test methods Part 1 : Basidiomycetes. CEN/TS 15083-1. Brussels.

4. Goodell, B., Nicholas, D.D., \& Schultz, T.P. (eds). (2003). Wood deterioration and preservation. Advances in our changing world. Washington, DC: American Chemical Society (ACS).

5. Irbe, I., Sansonetti, E., Zudrags, K., Andersone, I., \& Andersons, B. (2016). Fungal resistance of different plywood types during outdoor exposure. In 27th International Conference on Wood Science and Technology, 1314 October 2016 (pp. 8997). Zagreb, Croatia: University of Zagreb, Faculty of Forestry.

6. Leja, K., \& Lewandowicz, G. (2010). Polymer biodegradation and biodegradable polymers a review. Polish Journal of Environmental Studies, 19(2): 255266.

7. Lira, D.A., Silva, D.A., Filho, A.C., Lucas, E., \& Santana, S. (2017). Smectite clay modified with quaternary ammonium as oil remover. Journal of the Brazilian Chemical Society, 28, 2. DOI: 10.5935/01035053.20160165.

8. L’Association Francaise de Normalisation (AFNOR). (1980). Particle board. Test method for determining rot resistance (Basidiomycete fungi). NF B 51-295. Paris.

9. Latvijas Standarts. (2012). Plywood Specifications. LVS EN 636:2012. Riga.

10. Latvijas Standarts. (2002). Durability of wood and wood-based products. Wood based panels. Method of test for determining the resistance against wood-destroying basidiomycetes. LVS ENV 12038:2002. Riga 
11. Latvijas Standarts. (1995). Soil quality extraction of trace elements soluble in aqua regia. LVS ISO 11466:1995. Riga.

12. Lazdina, L., Obuka, V., \& Nikolajeva, V. (2017). The antimicrobial effect of modified clay materials. Abstract of the 75th Scientific Conference of the University of Latvia. Environmental and Experimental Biology, 15: 49. DOI: 10.22364/eeb.15.07.

13. Parolo, M.E., Fernández, L.G., Zajonkovsky, I., Sánchez, M.P., \& Baschini, M. (2011). Antibacterial activity of materials synthesized from clay minerals. In A. Méndez-Vilas (Eds.) Science against microbial pathogens: communicating current research and technological advances (pp. 144151). Bajadoz: Formatex Research Center.

14. R Core Team. (2017). R: A language and environment for statistical computing [computer software]. Vienna: R Foundation for Statistical Computing.

15. Schmidt, O. (2006). Wood and tree fungi. Berlin, Heidelberg: Springer-Verlag.

16. Tautkus, S., Steponeniene, L., \& Kazlauskas, R. (2004). Determination of iron in natural and mineral waters by flame atomic absorption spectrometry. Journal of the Serbian Chemical Society, 69(5): 393402.

17. Wickham, H., \& Bryan, J. (2017). readxl: Read Excel Files. R package version 1.0.0. https://CRAN.Rproject.org/package=readxl.

18. Williams, L.B., Metge, D.W., Eberl, D.D., Harvey, R.W., Turner, A.G., Prapaipong, P., \& Poret-Peterson, A.T. (2011). What makes a natural clay antibacterial? Environmental Science \& Technology, 45, 37683773. DOI: $10.1021 / \mathrm{es} 1040688$.

19. Youngquist, J.A. (1999). Wood-based composites and panel products. In: Wood Handbook: Wood as an Engineering Material. General Technical Report FPL-113, USDA, Forest Service, Forest Products Laboratory, Madison, Chapter 10: 131. 